OPEN ACCESS

Edited by:

Kezhen Qi,

Shenyang Normal University, China

Reviewed by:

Jian Zhang,

Wuhan University of

Technology, China

Qi Long Guo,

Northwest University for

Nationalities, China

*Correspondence:

Shulong Liu

liushulong0314@163.com

Specialty section

This article was submitted to

Nanoscience,

a section of the journal

Frontiers in Chemistry

Received: 26 December 2019 Accepted: 04 February 2020 Published: 25 February 2020

Citation:

Liu S, Yan P, Li H, Zhang X and Sun W

(2020) One-Step Microwave

Synthesis of Micro/Nanoscale $\mathrm{LiFePO} /$ /Graphene Cathode With High Performance for Lithium-Ion

Batteries. Front. Chem. 8:104

doi: 10.3389/fchem.2020.00104

\section{One-Step Microwave Synthesis of Micro/Nanoscale LiFePO 4 /Graphene Cathode With High Performance for Lithium-Ion Batteries}

\author{
Shulong Liu ${ }^{1 *}$, Ping Yan ${ }^{2}$, Haibin $\mathrm{Li}^{1}$, Xiaobo Zhang ${ }^{1}$ and Wei Sun ${ }^{1}$ \\ ${ }^{1}$ School of Physics and Electronic Information/Information College, Huaibei Normal University, Huaibei, China, ${ }^{2}$ School of Life \\ Science, Huaibei Normal University, Huaibei, China
}

In this study, micro/nanoscale $\mathrm{LiFePO}_{4}$ /graphene composites are synthesized successfully using a one-step microwave heating method. One-step microwave heating can simplify the reduction step of graphene oxide and provide a convenient, economical, and effective method of preparing graphene composites. The structural analysis shows that $\mathrm{LiFePO}_{4} /$ graphene has high phase purity and crystallinity. The morphological analysis shows that $\mathrm{LiFePO}_{4}$ /graphene microspheres and micron blocks are composed of densely aggregated nanoparticles; the nanoparticle size can shorten the diffusion path of lithium ions and thus increase the lithium-ion diffusion rate. Additionally, the graphene sheets can provide a rapid transport path for electrons, thus increasing the electronic conductivity of the material. Furthermore, the nanoparticles being packed into the micron graphene sheets can ensure stability in the electrolyte during charging and discharging. Raman analysis reveals that the graphene has a high degree of graphitization. Electrochemical analysis shows that the $\mathrm{LiFePO}_{4} /$ graphene has an excellent capacity, high rate performance, and cycle stability. The discharge capacities are 166.3, 156.1, 143.0, 132.4, and $120.9 \mathrm{mAh} \mathrm{g}^{-1}$ at rates of $0.1,1,3,5$, and $10 \mathrm{C}$, respectively. The superior electrochemical performance can be ascribed to the synergy of the shorter lithium-ion diffusion path achieved by $\mathrm{LiFePO}_{4}$ nanoparticles and the conductive networks of graphene.

Keywords: $\mathrm{LiFePO}_{4} /$ graphene composite, micro/nanoscale, one step, microwave synthesis, electrochemical performance

\section{INTRODUCTION}

Energy and materials, important pillars of the modern developing society, are closely related to human civilization. Rechargeable lithium-ion batteries, an environmentally friendly and new green energy, have wide applicability in the fields of energy storage and transportation (Song et al., 2018). The ever-increasing demand for high current charge-discharge capability, high energy density, and long service life has driven the development of the lithium battery industry (Zhou et al., 2019). Olivine phase lithium iron phosphate $\left(\mathrm{LiFePO}_{4}\right)$ is one of the focused cathode materials in lithiumion batteries (Padhi et al., 1997a,b). It has many superior properties, such as that $\mathrm{Fe}$ is low-cost and environmentally benign, that the covalently bonded $\mathrm{PO}_{4}$ groups make the chemical properties more stable and prolong service lifetime, and that it has a high theoretical capacity $\left(170 \mathrm{mAhg}^{-1}\right)$ 
and flat voltage plateau $\left(3.45 \mathrm{~V}\right.$ vs. $\left.\mathrm{Li} / \mathrm{Li}^{+}\right)$. However, $\mathrm{LiFePO}_{4}$ materials have some drawbacks, such as inferior electronic conductivity (ca.10 ${ }^{-9}-10^{-10} \mathrm{Scm}^{-1}$ ) as well as slow onedimensional lithium ion diffusion, which is a formidable obstacle to the high performance of lithium-ion batteries (Goodenough and Kim, 2010; Dathar et al., 2011). A considerable number of methods have been adopted with the aim of alleviating the above shortcomings. These methods can be categorized into two main classes: particle size control (Prosini et al., 2003; Zhao et al., 2016) and conductive material coating (Chang et al., 2019; Han et al., 2019; Ma et al., 2019; Tao et al., 2019).

Small particle size can decrease the migration distance of lithium ions from the interior to the surface and increase the diffusion rate ( $\mathrm{Lim}$ et al., 2008; Hai et al., 2019; Li et al., 2019; Xiao et al., 2019). Various techniques, including solid-state reaction (Zheng et al., 2008), sol-gel (Zhang et al., 2011) hydrothermal (Kiyoshi et al., 2008; Chang et al., 2014), co-precipitation (Park et al., 2003; Wang et al., 2013), and microwave heating (Wang et al., 2007; Beninati et al., 2008; Guo et al., 2010), are adopted to control particle size. Moreover, surface coating with conductive material can increase the electronic conductivity between particles (Wang et al., 2010; Fathollahi et al., 2015; Ahn et al., 2019) and provide paths in all directions for the fast transmission of electrons (Wang et al., 2009; Jang et al., 2011; Fan et al., 2014). Graphene with high electrical conductivity has been adopted to improve the cycling stability and rate capability of cathode material (Ding et al., 2010; Zhou et al., 2011; Shi et al., 2012; Tang et al., 2012; Chen et al., 2018; Wang et al., 2018). Ding et al. (2010) prepared nano-structured $\mathrm{LiFePO}_{4} /$ graphene using co-precipitation and sintering at $700^{\circ} \mathrm{C}$ for $18 \mathrm{~h}$ under argon flow. Shi et al. (2012) prepared graphene-wrapped $\mathrm{LiFePO}_{4} / \mathrm{C}$ using a microwaveassisted hydrothermal method, followed by sintering at $600^{\circ} \mathrm{C}$ for $2 \mathrm{~h}$ under $\mathrm{H}_{2} / \mathrm{Ar}$ flow. Zhou et al. (2011) first synthesized $\mathrm{LiFePO}_{4}$ nanoparticles by a hydrothermal method and then synthesized $\mathrm{LiFePO}_{4} /$ graphene from $\mathrm{LiFePO}_{4}$ nanoparticles and graphene oxide nanosheets by spray-drying and annealing processes. Tang et al. (2012) synthesized $\mathrm{LiFePO}_{4} /$ graphene by mixing three-dimensional graphene prepared by chemical vapor deposition and $\mathrm{LiFePO}_{4}$ prepared by solid-state reaction in a N-methyl pyrrolidinone (NMP) suspension. The above experimental methods are very complicated, and most of them require long-term high-temperature treatment and atmosphere protection, which lead to high energy consumption and cost. Additionally, the graphene and active materials agglomerate easily and distribute unevenly. Therefore, simplifying the preparation technology and obtaining a product with a small and homogeneous distribution remain great challenges for preparing $\mathrm{LiFePO}_{4} /$ graphene composites. Microwave heating is a convenient, economical, and environmentally friendly route for the preparation of graphene composites in a way that addresses the deficiency of graphene modification. Microwave heating can simplify the reduction step of graphene oxide, as, due to the microwave-absorbing properties of graphene oxide, microwave irradiation can restore it into graphene directly without any reductive agent and atmosphere.
In this work, micro/nanoscale $\mathrm{LiFePO}_{4} /$ graphene composites are synthesized successfully using a one-step microwave heating method. The synthesis technique has a decisive influence on the structure, morphology, and electrochemical properties of the $\mathrm{LiFePO}_{4}$ product. Microwave synthesis can save synthesis time; this is because the raw material can absorb microwave energy by itself and convert electromagnetic energy into heat and internal molecular kinetic energy, thus improving the diffusion coefficient and accelerating the reaction rate. Meanwhile, microwave synthesis can lower the synthesis temperature; this is because the electromagnetic field decreases the activation energy of the reaction. Therefore, microwave heating is a rapid and effective synthetic method for preparing a product with small particle size. Furthermore, unlike in complex, multi-step preparation processes, microwave irradiation can restore the graphene oxide into graphene directly without any reductive agent and atmosphere. The synthesized micro/nanoscale $\mathrm{LiFePO}_{4} /$ graphene composites with fine particle size and uniform distribution can decrease the migration distance of lithium ions from the interior to the surface and increase the diffusion rate. Meanwhile, graphene wrapping of the surface of $\mathrm{LiFePO}_{4}$ particles can guarantee that the electrons migrate to the active sites quickly. Controlling the particle size and coating with graphene play important roles in the electrochemical performance. The effects of graphene and microwave irradiation on the electrochemical performance of $\mathrm{LiFePO}_{4} /$ graphene cathode materials for lithium-ion batteries are further investigated.

\section{EXPERIMENTAL}

\section{Preparation of Materials}

$\mathrm{FeSO}_{4} \cdot 7 \mathrm{H}_{2} \mathrm{O}(99 \%), \mathrm{LiOH} \cdot \mathrm{H}_{2} \mathrm{O}(95 \%), \mathrm{H}_{3} \mathrm{PO}_{4}$ (85\%), ethylene glycol, and sucrose were purchased from Sinopharm Chemical Reagent Co. Ltd. Graphene oxide was synthesized from natural graphite powder (325 mesh) using a modified Hummers' method (Kovtyukhova et al., 1999; Stankovich et al., 2007).

The $\mathrm{LiFePO}_{4} /$ graphene and $\mathrm{LiFePO}_{4} / \mathrm{C}$ composites were synthesized via the following steps. $\mathrm{FeSO}_{4} \cdot 7 \mathrm{H}_{2} \mathrm{O}$ and $\mathrm{H}_{3} \mathrm{PO}_{4}$ were dissolved in a mixed solution of de-ionized water and ethylene glycol, and GO suspension was added to the solution. Next, a mixture of $\mathrm{LiOH} \cdot \mathrm{H}_{2} \mathrm{O}$ aqueous solution and GO suspension was added into the mixed solution under constant stirring. The molar ratio of Li:Fe:P is 3:1:1. After stirring for $3 \mathrm{~h}$, the solution was evaporated at $80^{\circ} \mathrm{C}$ for $12 \mathrm{~h}$. Meanwhile, a separate sample was prepared with the GO suspension replaced by sucrose as the source of carbon, and the previous steps were repeated. Finally, the precursors obtained were pressed into pellets, and then the pellets were placed inside a quartz crucible with a cover to prevent air oxidation. The quartz crucible was put in the middle of the domestic microwave oven, and the precursors were radiated by microwave for $10 \mathrm{~min}$ with a maximum power of $1,500 \mathrm{~W}$ and a frequency of $2.45 \mathrm{GHz}$. After microwave irradiation, $\mathrm{LiFePO}_{4} /$ graphene and $\mathrm{LiFePO}_{4} / \mathrm{C}$ composites were obtained, respectively. 


\section{Characterization Techniques}

The structures of $\mathrm{LiFePO}_{4} /$ graphene and $\mathrm{LiFePO}_{4} / \mathrm{C}$ composites were investigated using an X-ray diffractometer (X'pert PRO, Panalytical, Holland) with $\mathrm{Cu} \mathrm{K} \alpha$ radiation operated at $40 \mathrm{kV}$ and $40 \mathrm{~mA}$. The contents of graphene and carbon in the $\mathrm{LiFePO}_{4} /$ graphene and $\mathrm{LiFePO}_{4} / \mathrm{C}$ composites were calculated from TG-DSC (STA449F3, NETZSCH, Germany), which was carried out from room temperature to $700^{\circ} \mathrm{C}$ under an air atmosphere at a rate of $10^{\circ} \mathrm{C} \mathrm{min}^{-1}$. The morphologies of $\mathrm{LiFePO}_{4}$ /graphene composites were observed using a scanning electron microscope (SEM, JSM-IT300 at 20 $\mathrm{kV}$ ) and transmission electron microscopy (TEM, JEM2100F Japan at $200 \mathrm{kV}$ ). The Raman spectra of $\mathrm{LiFePO}_{4} /$ graphene and $\mathrm{LiFePO}_{4} / \mathrm{C}$ composites were recorded from 100 to $3,200 \mathrm{~cm}^{-1}$ on a Renishaw Raman microprobe (INVIA, China) using a $514.5 \mathrm{~nm}$ argon-ion laser at room temperature.

\section{Cell Fabrication and Electrochemical Measurement}

The electrochemical behaviors of the $\mathrm{LiFePO}_{4} /$ graphene and $\mathrm{LiFePO}_{4} / \mathrm{C}$ composites were evaluated with 2,025 coin-type batteries. The cathode electrodes were prepared by mixing $80 \mathrm{wt} \%$ active materials $\left(\mathrm{LiFePO}_{4} /\right.$ graphene or $\mathrm{LiFePO}_{4} / \mathrm{C}$ ) and $10 \mathrm{wt} \%$ carbon black (TIMCAL) with $10 \mathrm{wt} \%$ polytetrafluoroethylene (PTFE, Aldrich) in isopropyl alcohol solution (99.5\%, Aldrich). A uniform slurry was formed and pasted onto $\mathrm{Al}$ foils, dried at $120^{\circ} \mathrm{C}$ for $12 \mathrm{~h}$, and then cut into circular electrodes with a diameter of $10 \mathrm{~mm}$. Lithium metal (99.9\%, Alfa-Aesar) was used as the anode, Celgard polypropylene (Celgard 2400) as the separator, and $1 \mathrm{M} \mathrm{LiPF}_{6}$ dissolved in ethylene carbonate and dimethyl carbonate (with a 1:1 volume ratio) as the electrolyte (MERCK KGaA, Germany). The cells were assembled in an argon-filled glove box (Etelux Lab2000, China). Cells were charged and discharged at room temperature using a LAND-CT2001A battery cycler (Wuhan, China) within the voltage range of $2.7-4.2 \mathrm{~V}$ (vs. $\mathrm{Li}^{+} / \mathrm{Li}$ ). Cyclic voltammetry $(\mathrm{CV})$ was performed with an Auto Potentiostat 30 system at a scan rate of $0.1 \mathrm{mVs}^{-1}$ between 2.5 and $4.2 \mathrm{~V}$. Electrochemical impedance spectroscopy (EIS) profiles were obtained at the same open-circuit voltage by applying a $5-\mathrm{mV}$ amplitude of the $\mathrm{AC}$ voltage with the frequency ranging from $100 \mathrm{kHz}$ to $0.01 \mathrm{~Hz}$.

\section{RESULTS AND DISCUSSION}

\section{Phase Structural Analysis}

The phase constitution and crystal structure of the synthetic $\mathrm{LiFePO}_{4}$ /graphene and $\mathrm{LiFePO}_{4} / \mathrm{C}$ composites are here investigated. XRD patterns of the composites are shown in Figure 1. It can be seen that there is no noticeable difference between $\mathrm{LiFePO}_{4} /$ graphene and $\mathrm{LiFePO}_{4} / \mathrm{C}$ composites. All the sharp diffraction peaks corresponding to the (200), (101), (210), (011), (111), (211), (301), (311), (121), (410), (221), (401), (112), (222), and (123) planes can be indexed to the orthorhombic olivine-type structure $\mathrm{LiFePO}_{4}$ with the Pnma space group (JCPDS card No. 83-2092) (Wang et al., 2009, 2010), and no excess impurity peaks are observed. The results

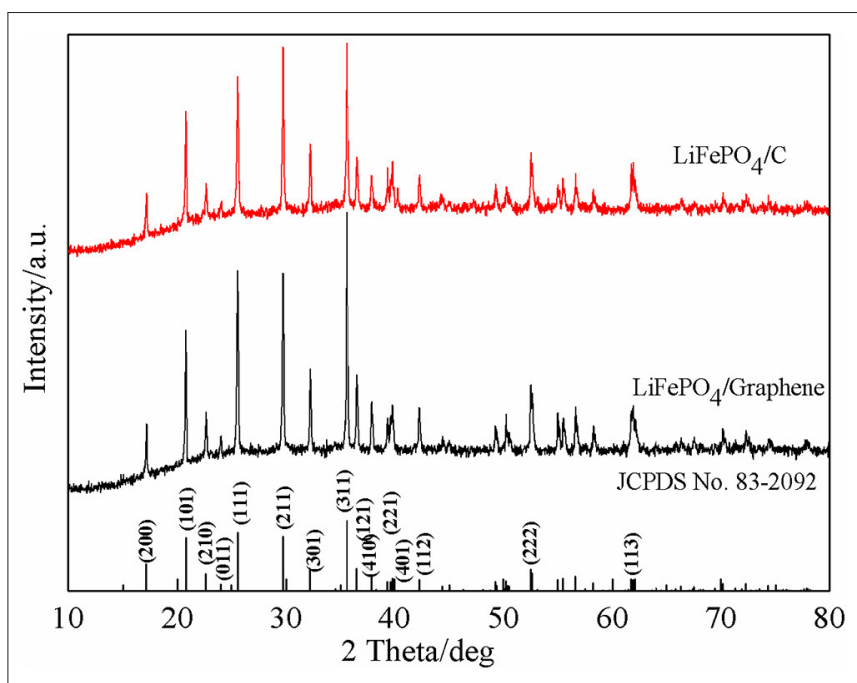

FIGURE 1 | XRD patterns of the $\mathrm{LiFePO}_{4} /$ graphene and $\mathrm{LiFePO}_{4} / \mathrm{C}$ composites.

manifest that the synthetic composites have high crystallinity and purity; this is mainly because microwave synthesis has the advantage of increasing the crystallinity and purity of products. The diffraction pattern of $\mathrm{LiFePO}_{4}$ /graphene shows that no diffraction peak of graphene oxide (at around $12^{\circ}$ ) is observed, proving that the graphene oxide has already been reduced into graphene directly without any reducing agent or atmosphere. This is mainly because the graphene oxide with a large amount of oxygen functional groups on the surface that can absorb microwaves easily, and electromagnetic energy is converted into heat and molecular kinetic energy; the reactive oxygen groups are then exfoliated, and, finally, the graphene oxide is restored into graphene. Also, the introduction of graphene has no effect on the structure of $\mathrm{LiFePO}_{4}$. Moreover, the diffraction pattern of $\mathrm{LiFePO}_{4} / \mathrm{C}$ shows no diffraction peaks corresponding to residual carbon, indicating that the carbon decomposed from sucrose in the sample exists in an amorphous state.

\section{TG-DSC Analysis}

TG-DSC measurement data is used to estimate the graphene and carbon content in the $\mathrm{LiFePO}_{4} /$ graphene and $\mathrm{LiFePO}_{4} /$ carbon composites, as shown in Figure 2. The pure $\mathrm{LiFePO}_{4}$ can be completely oxidized to $\mathrm{Li}_{3} \mathrm{Fe}_{2}\left(\mathrm{PO}_{4}\right)_{3}$ and $\mathrm{Fe}_{2} \mathrm{O}_{3}$ under air flow, and the total weight gain is about $5.07 \%$ in theory (Belharouak et al., 2005; Bai et al., 2015). For $\mathrm{LiFePO}_{4}$ /graphene and $\mathrm{LiFePO}_{4} /$ carbon composites, in the temperature range of $400-600^{\circ} \mathrm{C}$, the graphene and carbon are oxidized to $\mathrm{CO}_{2}$ gas, so the amounts of graphene and carbon in the $\mathrm{LiFePO}_{4}$ /graphene and $\mathrm{LiFePO}_{4} /$ carbon composites are about 1.40 and $10.70 \%$, respectively.

\section{Raman Analysis}

Raman scattering spectroscopy was employed to recognize the chemical structure of the $\mathrm{LiFePO}_{4} /$ graphene and $\mathrm{LiFePO}_{4} / \mathrm{C}$ composites; the results are shown in Figure 3. The main vibration 


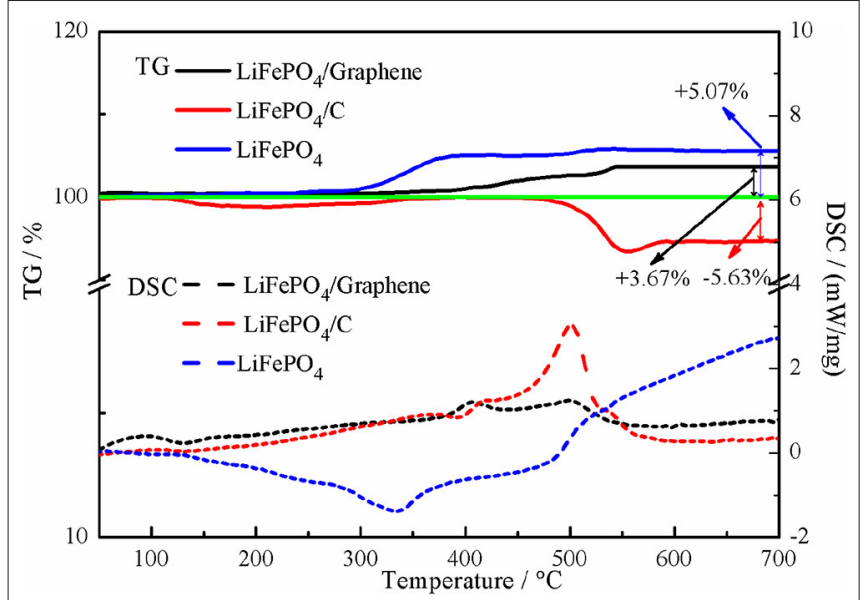

FIGURE 2 | TG-DSC curves of $\mathrm{LiFePO}_{4} /$ graphene, $\mathrm{LiFePO}_{4} / \mathrm{C}$ composites, and $\mathrm{LiFePO}_{4}$.

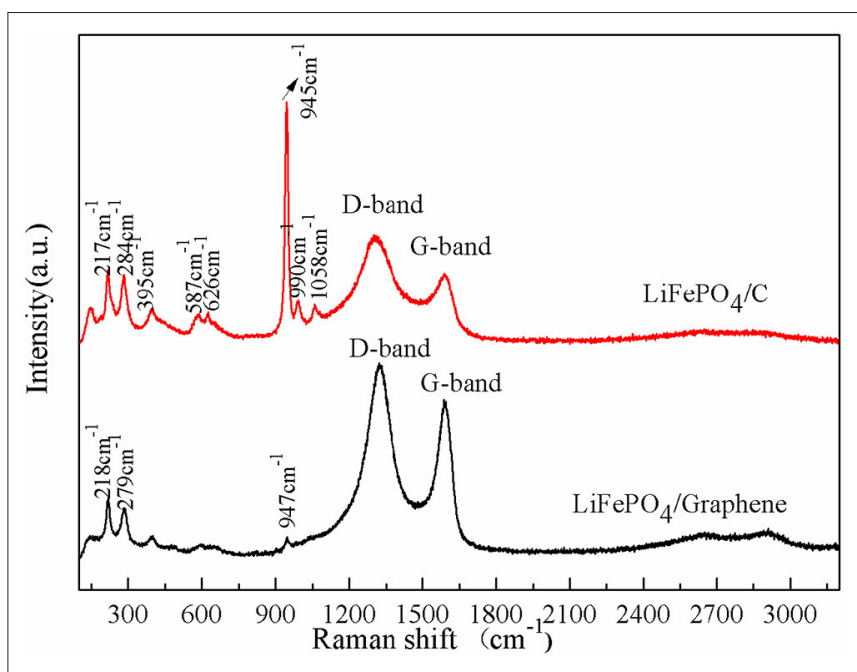

FIGURE 3 | Raman spectra of $\mathrm{LiFePO} /$ graphene and LiFePO $/$ / C composites. modes include internal modes attributable to $\mathrm{PO}_{4}^{3-}$ anions and external modes attributable to the coupled motion of $\mathrm{Fe}^{2+}$ and $\mathrm{PO}_{4}^{3-}$ (Markevich et al., 2011). The modes at 990, 1,058, and $945 \mathrm{~cm}^{-1}$ correspond to the anti-symmetric ( $\left.\nu 3\right)$ and symmetric (v1) stretching of the P-O bonds. The modes at 626 and 587 $\mathrm{cm}^{-1}$ correspond to the symmetric ( $\left.\nu 2\right)$ and anti-symmetric ( $\left.\nu 4\right)$ bending of the $\mathrm{O}-\mathrm{P}-\mathrm{O}$ angles. The mode at $395 \mathrm{~cm}^{-1}$ corresponds to the lithium cage and oxygen ion breathing cage. The modes in the $100-300 \mathrm{~cm}^{-1}$ range are induced by translation of $\mathrm{Fe}$ and coupled translation and vibration of $\mathrm{Fe}$ and $\mathrm{PO}_{4}^{3-}$ (Burba and Frech, 2004; Wu et al., 2013). Moreover, there are two obvious $\mathrm{D}$ band peaks at around $1,310 \mathrm{~cm}^{-1}$ and a $\mathrm{G}$ band at around $1,590 \mathrm{~cm}^{-1}$ (Tuinstra and Koenig, 1970). The D band is induced by a disordered and defective carbon structure in the crystal plane of the short-order $s p^{2}$ and $s p^{3}$ carbon. The $G$ band is assigned to the in-plane bond-stretching motion of $s p^{2}$ carbon atoms. The intensity ratio of the $\mathrm{D}$ and $\mathrm{G}$ bands $\left(I_{\mathrm{D}} / I_{\mathrm{G}}\right)$ is inversely proportional to the degree of graphitization of carbon materials. The $I_{\mathrm{D}} / I_{\mathrm{G}}$ in $\mathrm{LiFePO}_{4} /$ graphene composites is 1.18 , while the $I_{\mathrm{D}} / I_{\mathrm{G}}$ in $\mathrm{LiFePO}_{4} / \mathrm{C}$ composites is 1.43 . This implies that the graphene has a higher degree of graphitization than the carbon decomposed from sucrose. The higher the degree of graphitization, the better the conductivity of the carbon. A high degree of graphitization is favorable for electron transfer and improves the electrochemical performance of the cathode. Additionally, the strong signals of the graphene ( $\mathrm{D}$ band and $\mathrm{G}$ band) weaken and override the bands of $\mathrm{LiFePO}_{4}$ in the high-frequency region.

\section{Morphological Analysis}

SEM images of the graphene oxide and $\mathrm{LiFePO}_{4} /$ graphene are shown in Figures 4A-F. Figure 4A shows that the micron-scale graphene oxide sheets aggregate into petal shapes; these sheets can provide implantation sites for the adhesion of reaction particles. Figures $4 \mathbf{B}, \mathrm{C}$ clearly shows that the $\mathrm{LiFePO}_{4} /$ graphene composites are composed of micron-scale spheres and blocks with average dimensions of $\sim 2 \mu \mathrm{m}$. In Figures $4 \mathrm{D}-\mathrm{F}$, it can be clearly observed that these $\mathrm{LiFePO}_{4}$ /graphene microspheres and micron blocks are composed of densely aggregated nanoparticles. This structure forms because the self-heating effect induced by the microwave heating can greatly shorten the reaction time, and the graphene wrapping the surface of $\mathrm{LiFePO}_{4}$ particles can inhibit the growth of grains. Under the action of graphene, the nanoparticles assembled into microspheres and micron blocks. When the highly conductive electrolyte penetrates into the cathode material, the nanoparticles have a high specific surface area, which increases the contact area with the electrolyte. The nanoparticle size can shorten the diffusion paths of electrons and lithium ions and improve the conductivity of the cathode material significantly. Moreover, the micron structure formed by the aggregation of nanoparticles does not collapse during the process of lithium-ion intercalation and deintercalation, which ensures the stability of cathode material in the electrolyte. TEM and HRTEM images of the micron/nanoscale $\mathrm{LiFePO}_{4}$ /graphene composite are shown in Figures 4G,H. The ultrathin graphene sheets successfully form an effective conducting network and intrinsically bridge and intimately connect the active $\mathrm{LiFePO}_{4}$ particles. Figure $4 \mathbf{H}$ indicates that the graphene sheets around $\mathrm{LiFePO}_{4}$ are highly graphitic. The highly efficient and stable conducting network can give the material desirable electrochemical properties. In the energy spectrum, elements of $\mathrm{P}, \mathrm{O}, \mathrm{Fe}$, and $\mathrm{C}$ are found, as shown in Figure 4I; Li cannot be detected because of its very low atomic weight.

The formation process of the $\mathrm{LiFePO}_{4}$ /graphene composites is illustrated in Figure 5. At the initial stage of the reaction, the chemical reaction follows a dissolution-precipitation mechanism. The iron ions, phosphate ions, and lithium ions in the solution react with each other and form agglomerated precipitate on the surface of the graphene oxide sheets, and a large number of active functional groups are adsorbed on the surface of graphene oxide. At the stage of microwave irradiation, 

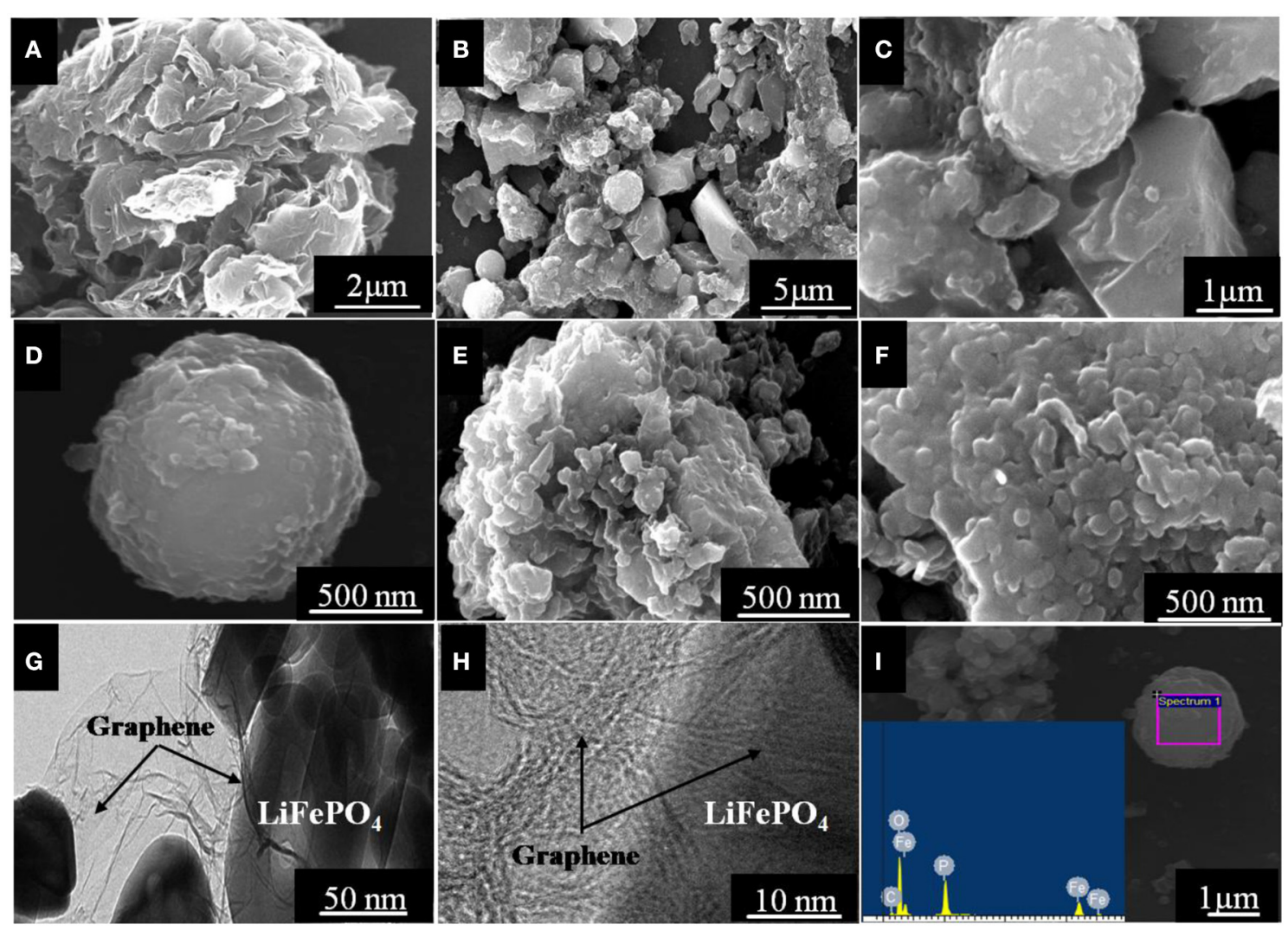

FIGURE 4 | SEM images of the graphene oxide (A) and LiFePO 4 /graphene (B-F); TEM and HRTEM images of the LiFePO $4 /$ graphene composites (G,H); EDS spectra of the $\mathrm{LiFePO}_{4} /$ graphene composites (I).

the active functional groups, being polar molecules, can absorb microwave easily, and electromagnetic energy is converted into heat and molecular kinetic energy. The temperature increase quickly, the reactive oxygen groups are exfoliated, and, finally, the graphene oxide is restored into graphene. Meanwhile, the precipitated particles adsorbed on the surface of reduced graphene sheets become hot and absorb microwaves quickly, the particles interact with each other, and then crystal nuclei are formed quickly under the action of the microwave electromagnetic field. Finally, under the influence of micron graphene sheets, the crystal nuclei grow, agglomerate, and form microspheres and micron blocks.

\section{Electrochemical Properties Analysis}

A schematic diagram of $\mathrm{LiFePO}_{4} /$ graphene electrode dynamics is shown in Figure 6. Transportation of electrons and ions $\left(e^{-}\right.$and $\left.\mathrm{Li}^{+}\right)$from their "reservoirs" toward the $\mathrm{LiFePO}_{4}$ particles (Gaberscek et al., 2007; Gaberscek, 2009) is shown as step A. A charge incorporation reaction that involves the transfer of $\mathrm{e}^{-}$and $\mathrm{Li}^{+}$from the outside into the interior of active particles is shown as step $B$, and the transport of the lithium component inside the solid active particles (solid-state diffusion) is shown as step C. It can be seen that graphene can provide a high-speed channel for the rapid diffusion of electrons and cause the electrons to reach the reactive site quickly, thus increasing the electronic conductivity of the materials. Meanwhile, the nanoparticles can shorten the transport path of $\mathrm{Li}^{+}$from the surface to the interior of solid active particles and improve the diffusion coefficient of lithium ions. Moreover, the nanoparticles are surrounded by the micron graphene sheets, and the micron structure guards the stability of the material. Therefore, $\mathrm{LiFePO}_{4} /$ graphene composites are expected to have excellent electrochemical performance.

Cyclic voltammetry was performed to investigate the electrochemical kinetics of $\mathrm{LiFePO}_{4} /$ graphene and $\mathrm{LiFePO}_{4} / \mathrm{C}$ cathode materials. Figure 7 shows the $\mathrm{CV}$ spectra of the $\mathrm{LiFePO}_{4} /$ graphene and $\mathrm{LiFePO}_{4} / \mathrm{C}$ composites. In the first scan, there is a pair of redox peaks corresponding to the $\mathrm{Fe}^{2+} / \mathrm{Fe}^{3+}$ couple (Ding et al., 2010; Zhou et al., 2011). The shapes of redox peaks are low and asymmetrical; this is because, in the first charging and discharging cycle, active materials are not completely saturated by electrolyte, and the pathways of lithium ion insertion and extraction were not completely formed. In the second scan, the current intensity increases, and the shape of the redox peaks becomes more symmetrical and sharper. For $\mathrm{LiFePO}_{4} /$ graphene, the potential difference between the oxidation and reduction peaks decreases from 0.27 to $0.26 \mathrm{~V}$, which means that the phase is stabilized in subsequent cycles. Figure 7B shows the $\mathrm{CV}$ spectra of $\mathrm{LiFePO}_{4} / \mathrm{C}$ composites. During the second scan, the potential difference increases 

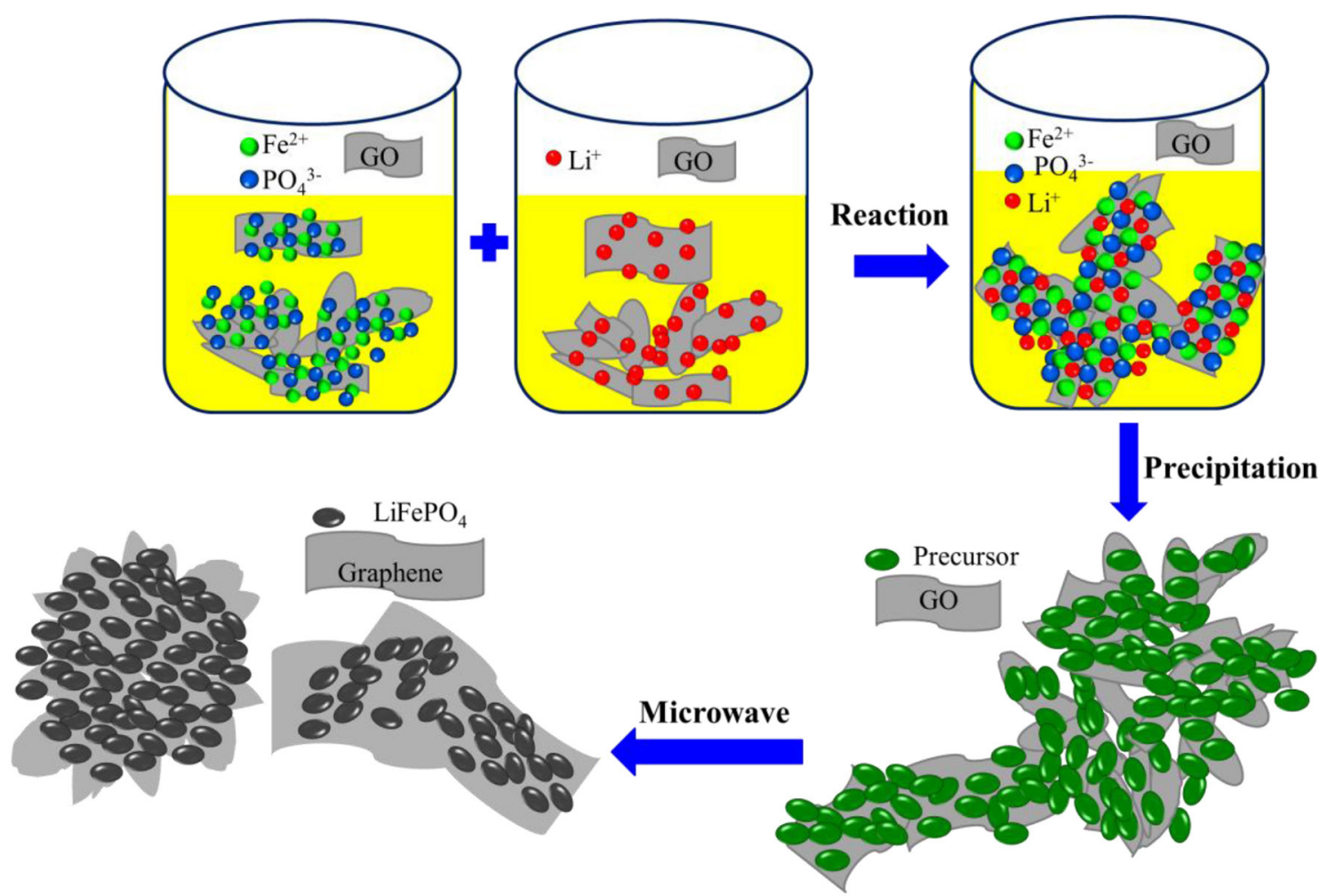

FIGURE 5 | Schematic illustration of the formation process of $\mathrm{LiFePO}_{4} /$ graphene composites.

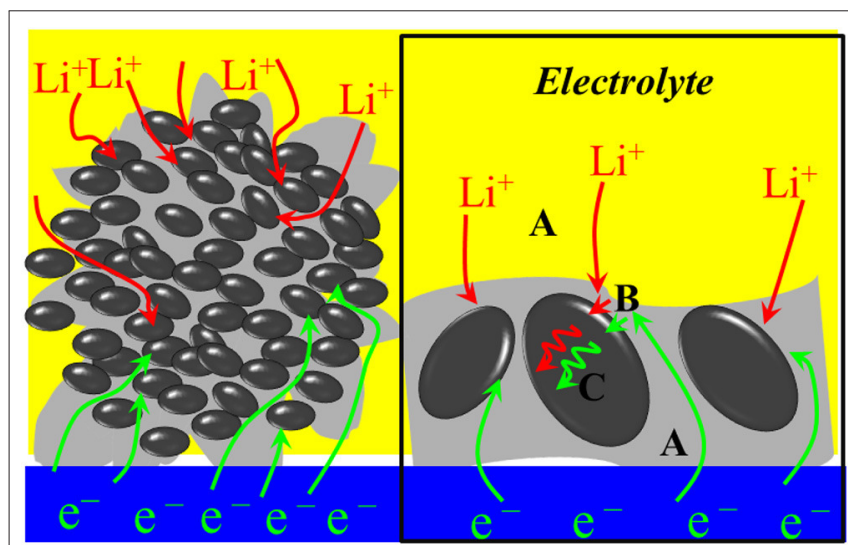

Aluminium foil

FIGURE 6 | Schematic diagram of $\mathrm{LiFePO}_{4} /$ graphene electrode dynamics.

from 0.31 to $0.33 \mathrm{~V}$, which proves that detrimental polarization becomes more and more serious. The results show that $\mathrm{LiFePO}_{4} /$ graphene composites have very high reversibility and better electrochemical activity.

The polarization of the $\mathrm{LiFePO}_{4} / \mathrm{C}$ electrode is explained by the electron transfer pathway, as shown in Figure 8A. The carbon is dispersed unevenly, so the electrons cannot reach the entire reactive site where the $\mathrm{Li}^{+}$ions intercalate. In contrast, for $\mathrm{LiFePO}_{4}$ /graphene, due to the one-dimensional $\mathrm{Li}^{+}$ion mobility in the framework, the graphene can ensure that electrons reach particles from all directions and alleviate the polarization, as shown in Figure 8B. Therefore, the $\mathrm{LiFePO}_{4} /$ graphene composites, with well-defined peaks and smaller potential difference, have higher electrochemical reactivity.

The charging and discharging capacity profiles of the $\mathrm{LiFePO}_{4} /$ graphene and $\mathrm{LiFePO}_{4} / \mathrm{C}$ at progressively increasing $\mathrm{C}$ rates from 0.1 to $10 \mathrm{C}$ are shown in Figure 9. The cells are cycled in the voltage window of $2.7-4.2 \mathrm{~V}$ at room temperature. For $\mathrm{LiFePO}_{4}$ /graphene composites, the initial discharge capacity is $166.3 \mathrm{mAhg}^{-1}$ at $0.1 \mathrm{C}$, and the discharge capacity decreases to $156.1 \mathrm{mAhg}^{-1}$ with an increase in the discharge rate to $1 \mathrm{C}$. At a higher discharge rate of $5 \mathrm{C}$, the cell delivers a capacity of $132.4 \mathrm{mAhg}^{-1}$. Even at a $10 \mathrm{C}$ rate, the capacities can reach $120.9 \mathrm{mAhg}^{-1}$, and a good voltage plateau remains above $3 \mathrm{~V}$. For $\mathrm{LiFePO}_{4} / \mathrm{C}$, the discharge capacity is $154.8,133.8,121.6$,

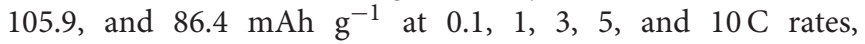
respectively. The cycling performances of the $\mathrm{LiFePO}_{4} /$ graphene and $\mathrm{LiFePO}_{4} / \mathrm{C}$ from 0.1 to $10 \mathrm{C}$ are shown in Figure 10. Although for $\mathrm{LiFePO}_{4}$ /graphene, the specific capacity decreases with increasing current rate, the capacity retention remains very good for all of the different rates; the discharge capacity retentions are, respectively, 99.5, 99.2, 99.4, 99.1, and 97.1\% at $0.1,1,3,5$, and $10 \mathrm{C}$ current rates after being cycled 10 times. While for $\mathrm{LiFePO}_{4} / \mathrm{C}$, the discharge capacity retentions 

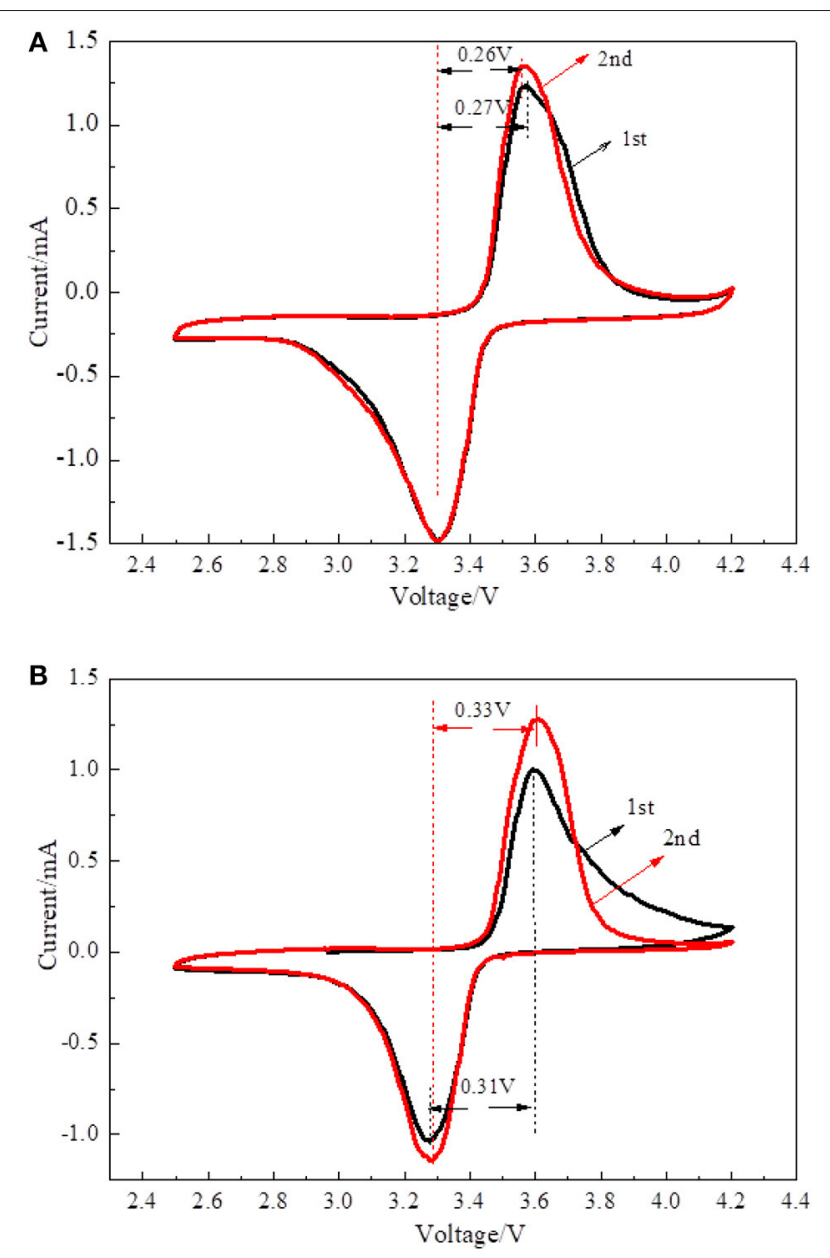

FIGURE 7 | Cyclic voltammetry curves of $\mathrm{LiFePO}_{4} /$ graphene (A) and $\mathrm{LiFePO}_{4} / \mathrm{C}$ (B) composites.

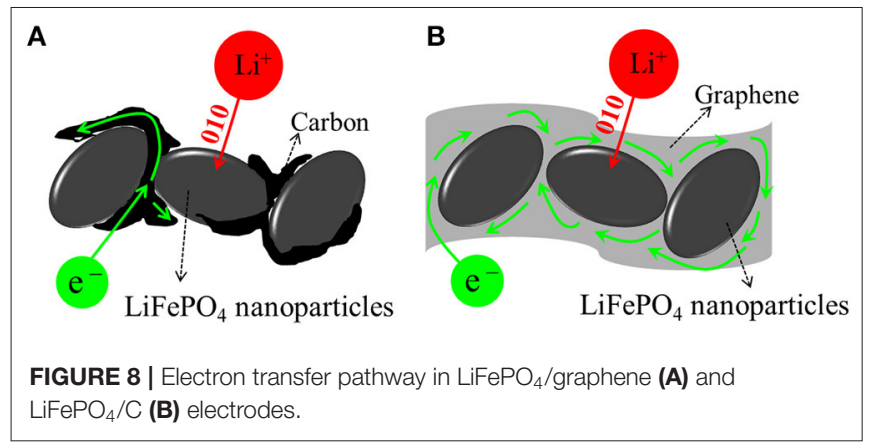

are, respectively, 97.7, 96.9, 93.0, 87.1, and $79.5 \%$ at $0.1,1,3$, 5 , and $10 \mathrm{C}$ current rates. All of the results demonstrate that $\mathrm{LiFePO}_{4} /$ graphene composites have better rate performance and cycling stability. This can be attributed to the excellent electrical conductivity of graphene, which can improve the conductivity and stability of materials.

Electrochemical impedance spectroscopy was used to investigate the electrochemical behaviors of $\mathrm{LiFePO}_{4} /$ graphene

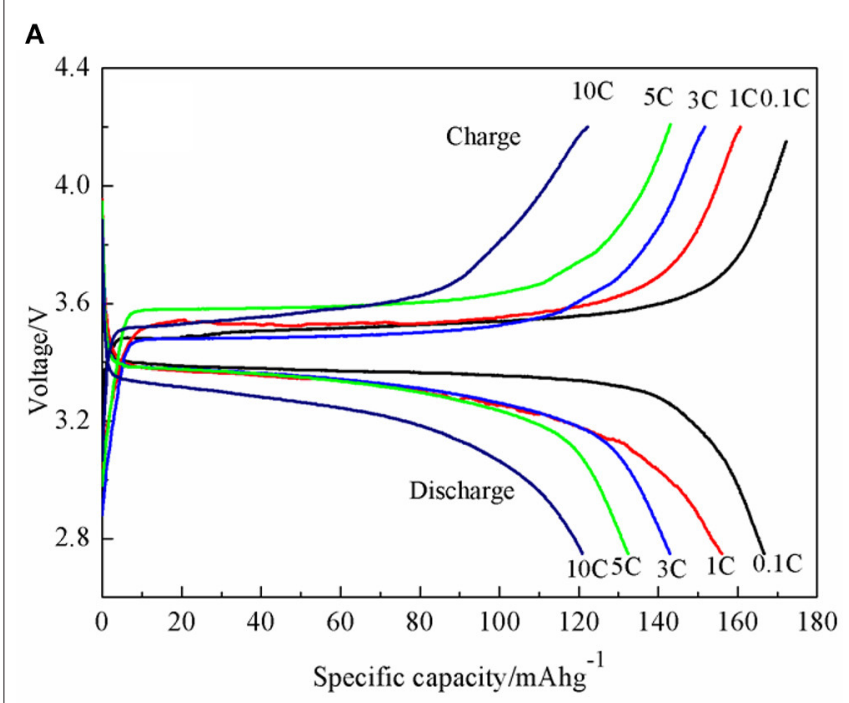

B

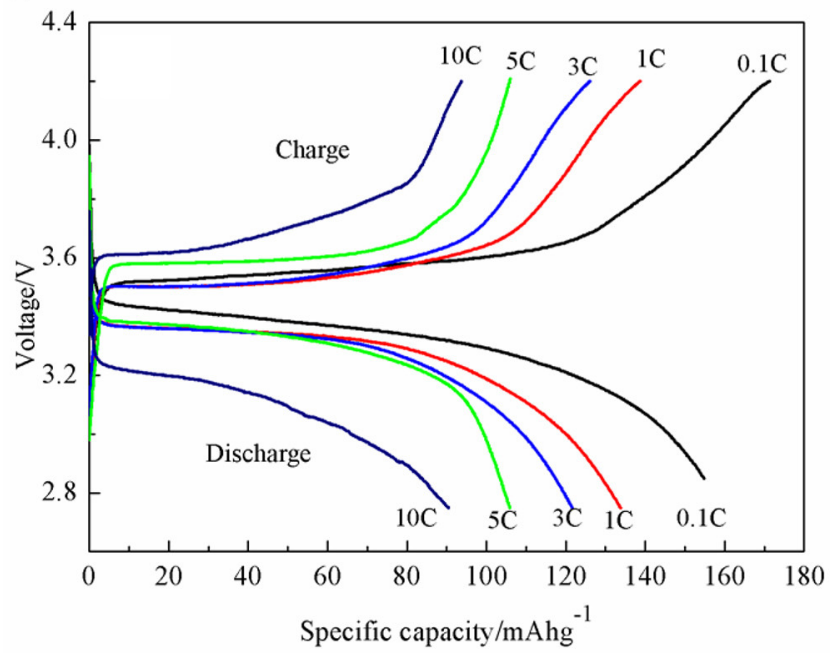

FIGURE 9 | Charge/discharge profiles of $\mathrm{LiFePO}_{4} /$ graphene (A) and $\mathrm{LiFePO}_{4} / \mathrm{C}$ (B) composites at various current rates ranging from 0.1 to $10 \mathrm{C}$.

and $\mathrm{LiFePO}_{4} / \mathrm{C}$ cathodes. Figure 11A shows the Nyquist plots of the $\mathrm{LiFePO}_{4} /$ graphene and $\mathrm{LiFePO}_{4} / \mathrm{C}$ cathodes. The experimental EIS data is simulated by Zview2.1 software according to the equivalent circuit as shown in Figure 11B. It can be found that all the Nyquist plots present a high-frequency quasi-semicircle, which is related to the migration of the $\mathrm{Li}^{+}$ ions at the electrode/electrolyte interface and the charge transfer process. Meanwhile, a low-frequency sloping line is related to the Warburg impedance of the lithium-ion diffusion in the electrode (Zhang et al., 2011). $R_{\mathrm{S}}$ is the internal resistance of the cell and corresponds to the electrodes, electrolyte, and the separator resistance, $R$ ct is associated with the chargetransfer resistance, $C P E$ is associated with the capacitance contributed by the surface of the active material (Guo et al., 2010). The simulation results show that the Rct value of the $\mathrm{LiFePO}_{4}$ /graphene cathode is $79 \Omega$, which is smaller than the 


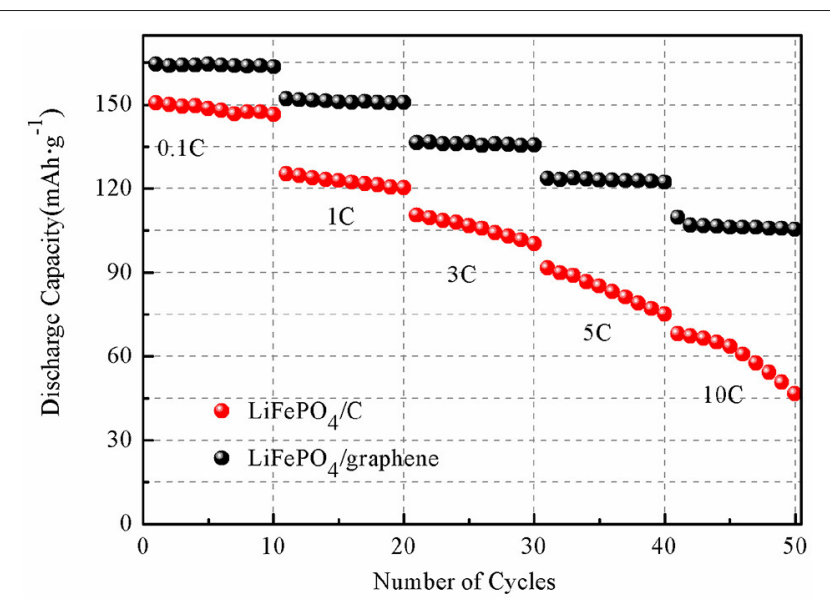

FIGURE 10 | Cycling performances of $\mathrm{LiFePO}_{4} /$ graphene (A) and $\mathrm{LiFePO}_{4} / \mathrm{C}$ (B) composites at various current rates ranging from 0.1 to $10 \mathrm{C}$.

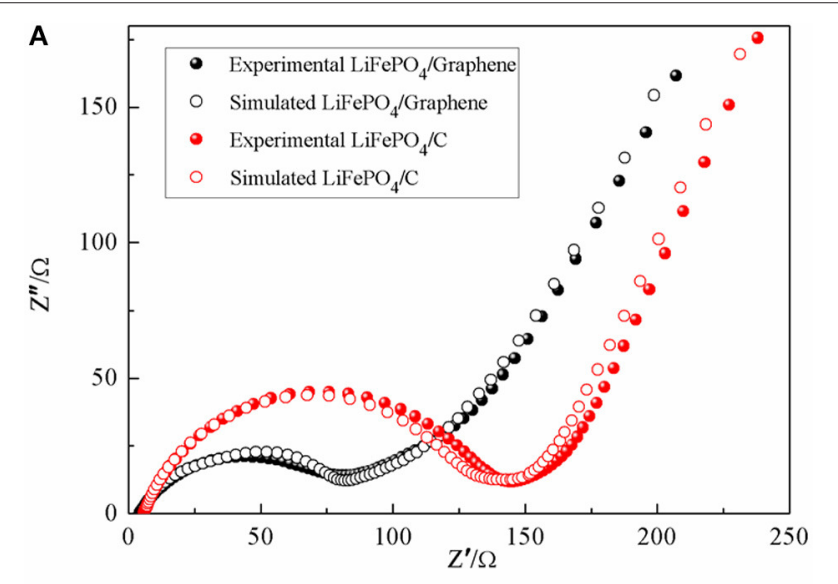

B

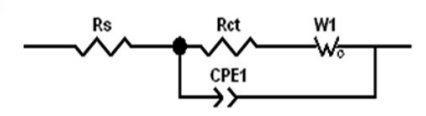

FIGURE 11 | Experimental and simulated electrochemical impedance spectra of $\mathrm{LiFePO}_{4} /$ graphene and $\mathrm{LiFePO}_{4} / \mathrm{C}$ composites (A); equivalent circuit (B).

$129 \Omega$ value of the $\mathrm{LiFePO}_{4} / \mathrm{C}$ cathode. The result shows that graphene can reduce the charge transfer resistance of Li-ion insertion and extraction between the electrode/electrolyte

\section{REFERENCES}

Ahn, W., Seo, M. H., Pham, T. K., Nguyen, Q. H., Luu, V. T., Cho, Y., et al. (2019). High lithium ion transport through rGO-wrapped $\mathrm{LiNi}_{0.6} \mathrm{Co}_{0.2} \mathrm{Mn}_{0.2} \mathrm{O}_{2}$ cathode material for high-rate capable lithium ion batteries. Front. Chem. 7:361. doi: $10.3389 /$ fchem.2019.00361

Bai, N. B., Chen, H., Zhou, W., Xiang, K. X., Zhang, Y. L., and Li, C. L. (2015). Preparation and electrochemical performance of $\mathrm{LiFePO}_{4} / \mathrm{C}$ microspheres by a facile and novel co-precipitation. Electrochim. Acta 167, 172-178. doi: 10.1016/j.electacta.2015. 03.163 and increase the conductivity of the $\mathrm{LiFePO}_{4} /$ graphene cathode.

\section{CONCLUSION}

A $\mathrm{LiFePO}_{4} /$ graphene composite was successfully prepared as cathode material through one-step microwave heating. The graphene oxide, which has excellent microwave-absorbing properties, can react with microwaves quickly and be restored into high-quality graphene directly without any reducing agent or atmosphere. The introduction of graphene does not impact the structure of $\mathrm{LiFePO}_{4}$, and $\mathrm{LiFePO}_{4}$ nanoparticles are packed into micron graphene sheets. The graphene network, which has a high degree of graphitization, can provide a high-speed channel for the rapid transfer of electrons and thus increase the electronic conductivity of materials. Meanwhile, the nanoparticles can improve the diffusion coefficient of lithium ions. Moreover, because the nanoparticles are surrounded by the graphene sheets, the micron structure guards the stability of the material. The electrochemical analyses reveal that the $\mathrm{LiFePO}_{4} /$ graphene composites have excellent high-rate performance and cycling life. The outstanding electrochemical performance, as well as the fast and efficient method, make this technology commercially viable.

\section{DATA AVAILABILITY STATEMENT}

The datasets generated for this study are available on request to the corresponding author.

\section{AUTHOR CONTRIBUTIONS}

SL, PY, and WS performed the experiments. SL, PY, HL, and $\mathrm{XZ}$ performed the data analysis. SL and PY wrote the paper. All authors contributed to the theoretical analysis and the general discussion.

\section{FUNDING}

This work was supported by the Program for Quality Engineering at School Level (2017jxcg01), Natural Science Foundation of Anhui Province (1708085QE119), Natural Science Foundation of Anhui Higher Education Institutions of China (KJ2015A314, KJ2017A393), and Collaborative Innovation Center of Advanced Functional Materials (XTZX103732016005).

Belharouak, I., Johnson, C., and Amine, K. (2005). Synthesis and electrochemical analysis of vapor-deposited carbon-coated $\mathrm{LiFePO}_{4}$. Electrochem. Commun. 7, 983-988. doi: 10.1016/j.elecom.2005.06.019

Beninati, S., Damen, L., and Mastragostino, M. (2008). MW-assisted synthesis of $\mathrm{LiFePO}_{4}$ for high power applications. J. Power Sources 180, 875-879. doi: 10.1016/j.jpowsour.2008.02.066

Burba, C. M., and Frech, R. (2004). Raman and FTIR spectroscopic study of $\mathrm{Li}_{x} \mathrm{FePO}_{4}(0 \leq x \leq 1)$. J. Electrochem. Soc. 151, A1032-A1038. doi: $10.1149 / 1.1756885$

Chang, M., Wang, H., Zheng, Y., Li, N., Chen, S., Wan, Y., et al. (2019). Surface modification of hollow microsphere $\mathrm{Li}_{1.2} \mathrm{Ni}_{1 / 3} \mathrm{Co}_{1 / 3} \mathrm{Mn}_{1 / 3} \mathrm{O}_{2}$ 
cathode by coating with $\mathrm{CoAl}_{2} \mathrm{O}_{4}$. J. Solid State Electrochem. 23, 607-613. doi: 10.1007/s10008-018-4157-y

Chang, Y. C., Hung, I. M., and Peng, C. T. (2014). Effects of particle size and carbon coating on electrochemical properties of $\mathrm{LiFePO}_{4} / \mathrm{C}$ prepared by hydrothermal method. J. Mater. Sci. 49, 6907-6916. doi: 10.1007/s10853-014-8395-9

Chen, H., Zhang, B., Zhang, J., Yu, W., Zheng, J., Ding, Z., et al. (2018). In-situ grown $\mathrm{SnS}_{2}$ nanosheets on $\mathrm{rGO}$ as an advanced anode material for lithium and sodium ion batteries. Front. Chem. 6:629. doi: 10.3389/fchem.2018.00629

Dathar, G. K. P., Sheppard, D., Stevenson, K. J., and Henkelman, G. (2011). Calculations of $\mathrm{Li}$ ion diffusion in olivine phosphates. Chem. Mater. 23, 4032-4037. doi: $10.1021 / \mathrm{cm} 201604 \mathrm{~g}$

Ding, Y., Jiang, Y., Xu, F., Yin, J., Ren, H., Zhuo, Q., et al. (2010). Preparation of nano-structured $\mathrm{LiFePO}_{4} /$ graphene composites by co-precipitation method. Electrochem. Commun. 12, 10-13. doi: 10.1016/j.elecom.2009.10.023

Fan, Q., Lei, L. X., Xu, X. Y., Yin, G., and Sun, Y. M. (2014). Direct growth of $\mathrm{FePO}_{4} /$ graphene and $\mathrm{LiFePO}_{4} /$ graphene hybrids for high rate Li-ion batteries. J. Power Sources 257, 65-69. doi: 10.1016/j.jpowsour.2014.01.044

Fathollahi, F., Javanbakht, M., Omidvar, H., and Ghaemi, M. (2015). Improved electrochemical properties of $\mathrm{LiFePO}_{4} /$ graphene cathode nanocomposite prepared by one-step hydrothermal method. J. Alloy Compd. 627, 146-152. doi: 10.1016/j.jallcom.2014.12.025

Gaberscek, M. (2009). Towards optimized preparation of cathode materials: how can modeling and concepts be used in practice. J. Power Sources 189, 22-27. doi: 10.1016/j.jpowsour.2008.12.041

Gaberscek, M., Dominko, R., and Jamnik, J. (2007). Is small particle size more important than carbon coating? an example study on $\mathrm{LiFePO}_{4}$ cathodes. Electrochem. Commun. 9, 2778-2783. doi: 10.1016/j.elecom.2007.09.020

Goodenough, J. B., and Kim, Y. (2010). Challenges for rechargeable Li batteries. Chem. Mater. 22, 587-603. doi: 10.1021/cm901452z

Guo, X. F., Zhang, Y. T., Zhan, H., and Zhou, Y. H. (2010). Investigation on the microwave-derived $\mathrm{LiFePO}_{4} / \mathrm{C}$ cathode material. Solid State Ion. 181, 1757-1763. doi: 10.1016/j.ssi.2010.10.008

Hai, Y., Zhang, Z., Liu, H., Liao, L., Fan, P., Wu, Y., et al. (2019). Facile controlled synthesis of spinel $\mathrm{LiMn}_{2} \mathrm{O}_{4}$ porousmicrospheres as cathode material for lithium ion batteries. Front. Chem. 7:437. doi: 10.3389/fchem.2019.00437

Han, Q. G., Zhang, W. Q., Han, Z. W., Wang, F. X., Geng, D., Li, X., et al. (2019). Preparation of PAN-based carbon fiber@ $\mathrm{MnO}_{2}$ composite as an anode material for structural lithium ion batteries. J. Mater. Sci. 54, 11972-11982. doi: 10.1007/s10853-019-03751-x

Jang, B. Z., Liu, C. G., Neff, D., Yu, Z. Y., Wang, M. C., Xiong, W., et al. (2011). Graphene surface-enabled lithium ion-exchanging cells: nextgeneration high-power energy storage devices. Nano. Lett. 11, 3785-3791. doi: $10.1021 / \mathrm{nl} 2018492$

Kiyoshi, K., Shohei, K., and Kaoru, D. (2008). Hydrothermal synthesis of $\mathrm{LiFePO}_{4}$ as a cathode material for lithium batteries. J. Mater. Sci. 43, 2138-2142. doi: 10.1007/s10853-007-2011-1

Kovtyukhova, N. I., Ollivier, P. J., Martin, B. R., Mallouk, T. E., Chizhik, S. A., Buzaneva, E. V., et al. (1999). Layer-by-layer assembly of ultrathin composite films from micron-sized graphite oxide sheets and polycations. Chem. Mater. 11, 771-778. doi: $10.1021 / \mathrm{cm} 981085 \mathrm{u}$

Li, Y., Zhang, H., Xiao, Z., and Wang, R. (2019). Flexible $\mathrm{Li}\left[\mathrm{Li}_{0.2} \mathrm{Ni}_{0.13} \mathrm{Co}_{0.13} \mathrm{Mn}_{0.54}\right] \mathrm{O}_{2} /$ carbon nanotubes/nanofibrillated celluloses composite electrode for high-performance lithium-ion battery. Front. Chem. 7:555. doi: $10.3389 /$ fchem. 2019.00555

Lim, S., Yoon, C. S., and Cho, J. (2008). Synthesis of nanowire and hollow $\mathrm{LiFePO}_{4}$ cathodes for high-performance lithium batteries. Chem. Mater. 20, 4560-4564. doi: $10.1021 / \mathrm{cm} 8006364$

Ma, F., Wu, Y. H., Wei, G., Qiu, S., and Qu, J. (2019). Enhanced electrochemical performance of $\mathrm{LiNi}_{0.8} \mathrm{Co}_{0.1} \mathrm{Mn}_{0.1} \mathrm{O}_{2}$ cathode via wetchemical coating of MgO. J. Solid State Electrochem. 23, 2213-2224. doi: 10.1007/s10008-019-04308-3

Markevich, E., Sharabi, R., Haik, O., Borgel, V., Salitra, G., Aurbach, D., et al. (2011). Raman spectroscopy of carbon-coated $\mathrm{LiCoPO}_{4}$ and $\mathrm{LiFePO}_{4}$ olivines. J. Power Sources 196, 6433-6439. doi: 10.1016/j.jpowsour.2011.03.059

Padhi, A. K., Nanjundaswamy, K. S., and Goodenough, J. B. (1997a). Phosphoolivines as positive electrode materials for rechargeable lithium batteries. J. Electrochem. Soc. 144, 1188-1194. doi: 10.1149/1.1837571
Padhi, A. K., Nanjundaswamy, K. S., Masquelier, C., and Goodenough, J. B. (1997b). Mapping of transition metal redox energies in phosphates with NASICON structure by lithium intercalation. J. Electrochem. Soc. 144, 2581-2586. doi: 10.1149/1.1837868

Park, K.-S., Son, J. T., Chung, H. T., Kim, S. J., Lee, C. H., and Kim, H. G. (2003). Synthesis of $\mathrm{LiFePO}_{4}$ by co-precipitation and microwave heating. Electrochem. Commun. 5, 839-842. doi: 10.1016/j.elecom.2003.08.005

Prosini, P. P., Carewska, M., Scaccia, S., Wisniewski, P., and Pasquali, M. (2003). Long-term cyclability of nanostructured $\mathrm{LiFePO}_{4}$. Electrochim. Acta 48, 4205-4211. doi: 10.1016/S0013-4686(03)00606-6

Shi, Y., Chou, S. L., Wang, J. Z., Wexler, D., Li, H. J., Liu, H. K., et al. (2012). Graphene wrapped $\mathrm{LiFePO}_{4} / \mathrm{C}$ composites as cathode materials for lithium-ion batteries. J. Mater. Chem. 22, 16465-16470. doi: 10.1039/c2jm $32649 \mathrm{c}$

Song, L., Tang, F., Xiao, Z., Cao, Z., and Zhu, H. (2018). Energy storage and thermostability of $\mathrm{Li}_{3} \mathrm{VO}_{4}$-coated $\mathrm{LiNi}_{0.8} \mathrm{Co}_{0.1} \mathrm{Mn}_{0.1} \mathrm{O}_{2}$ as cathode materials for lithium ion batteries. Front. Chem. 6:546. doi: 10.3389/fchem.2018. 00546

Stankovich, S., Dikin, D. A., Piner, R. D., Kohlhaas, K. A., Kleinhammes, A., Jia, Y. Y., et al. (2007). Synthesis of graphene-based nanosheets via chemical reduction of exfoliated graphite oxide. Carbon 45, 1558-1565. doi: 10.1016/j.carbon.2007.02.034

Tang, Y. F., Huang, F. Q., Bi, H., Liu, Z. Q., and Wan, D. Y. (2012). Highly conductive three-dimensional graphene for enhancing the rate performance of $\mathrm{LiFePO}_{4}$ cathode. J. Power Sources 203, 130-134. doi: 10.1016/j.jpowsour.2011.12.011

Tao, Y., Cao, Y. B., Hu, G. R., Chen, P. W., Peng, Z. D., Du, K., et al. (2019). Effects of vanadium oxide coating on the performance of $\mathrm{LiFePO}_{4} / \mathrm{C}$ cathode for lithium-ion batteries. J. Solid State Electrochem. 23, 2243-2250. doi: 10.1007/s10008-019-04319-0

Tuinstra, F., and Koenig, J. L. (1970). Raman spectrum of graphite. J. Chem. Phys. 53, 1126-1130. doi: 10.1063/1.1674108

Wang, G. X., Shen, X. P., Yao, J., and Park, J. (2009). Graphene nanosheets for enhanced lithium storage in lithium ion batteries. Carbon 47, 2049-2053. doi: 10.1016/j.carbon.2009.03.053

Wang, L., Huang, Y. D., Jiang, R. R., and Jia, D. Z. (2007). Preparation and characterization of nano-sized $\mathrm{LiFePO}_{4}$ by low heating solid-state coordination method and microwave heating. Electrochim. Acta 52, 6778-6783. doi: 10.1016/j.electacta.2007.04.104

Wang, L., Wang, H. B., Liu, Z. H., Xiao, C., Dong, S. M., Han, P. X., et al. (2010). A facile method of preparing mixed conducting $\mathrm{LiFePO}_{4} /$ graphene composites for lithium-ion batteries. Solid State Ion. 181, 1685-1689. doi: $10.1016 /$ j.ssi.2010.09.056

Wang, S. P., Yang, H. X., Feng, L. J., Sun, S. M., Guo, J. X., Yang, Y. Z., et al. (2013). A simple and inexpensive synthesis route for $\mathrm{LiFePO}_{4} / \mathrm{C}$ nanoparticles by co-precipitation. J. Power Sources 233, 43-46. doi: 10.1016/j.jpowsour.2013. 01.124

Wang, Y., Zhen, M., Liu, H., and Wang, C. (2018). Interlayer-expanded $\mathrm{MoS}_{2}$ /graphene composites as anode materials for high-performance lithium-ion batteries. J. Solid State Electrochem. 22, 3069-3076. doi: 10.1007/s10008-018-4018-8

Wu, J., Dathar, G. K. P., Sun, C. W., Theivanayagam, M. G., Applestone, D., Dylla, A. G., et al. (2013). In situ Raman spectroscopy of $\mathrm{LiFePO}_{4}$ : size and morphology dependence during charge and self-discharge. Nanotechnology 24:424009. doi: 10.1088/0957-4484/24/42/424009

Xiao, H., Huang, X., Ren, Y., Ding, X., and Zhou, S. (2019). Fabrication of $\mathrm{Li}_{4} \mathrm{Ti}_{5} \mathrm{O}_{12} @ \mathrm{CN}$ composite with enhanced rate properties. Front. Chem. 7:432. doi: 10.3389/fchem.2019.00432

Zhang, Y., Du, P. P., Wang, L. Z., Zhang, A. Q., Song, Y. H., Li, X. F., et al. (2011). Synthesis and electrochemical properties of gyroscopelike lithium iron phosphate/multiwalled carbon nanotubes composites by microwave-assisted sol-gel method. Synthetic Metals 161, 548-551. doi: 10.1016/j.synthmet.2011.01.008

Zhao, N. N., Li, Y. S., Zhao, X. X., Zhi, X. K., and Liang, G. C. (2016). Effect of particle size and purity on the low temperature electrochemical performance of $\mathrm{LiFePO}_{4} / \mathrm{C}$ cathode material. J. Alloys Compd. 683, 123-113. doi: 10.1016/j.jallcom.2016.04.070 
Zheng, J. C., Li, X. H., Wang, Z. X., Guo, H. J., and Zhou, S. Y. (2008). $\mathrm{LiFePO}_{4}$ with enhanced performance synthesized by a novel synthetic route. J. Power Sources 184, 574-577. doi: 10.1016/j.jpowsour.2008. 01.016

Zhou, P., Zhang, M., Wang, L., Huang, Q., Su, Z., Li, L., et al. (2019). Synthesis and electrochemical performance of ZnSe electrospinning nanofibers as an anode material for lithium ion and sodium ion batteries. Front. Chem. 7:569. doi: $10.3389 /$ fchem.2019.00569

Zhou, X. F., Wang, F., Zhu, Y. M., and Liu, Z. P. (2011). Graphene modified $\mathrm{LiFePO}_{4}$ cathode materials for high power lithium ion batteries. J. Mater. Chem. 21, 3353-3358. doi: 10.1039/c0jm03287e
Conflict of Interest: The authors declare that the research was conducted in the absence of any commercial or financial relationships that could be construed as a potential conflict of interest.

Copyright (c) $2020 \mathrm{Liu}$, Yan, Li, Zhang and Sun. This is an open-access article distributed under the terms of the Creative Commons Attribution License (CC BY). The use, distribution or reproduction in other forums is permitted, provided the original author(s) and the copyright owner(s) are credited and that the original publication in this journal is cited, in accordance with accepted academic practice. No use, distribution or reproduction is permitted which does not comply with these terms. 